\title{
WHO IS BESPEAKING TO WHOM? PLAINTIFF SOPHISTICATION, MARKET INFORMATION, AND FORWARD-LOOKING STATEMENTS
}

\author{
JONATHAN B. LURVEY
}

\section{INTRODUCTION}

The recently enacted Private Securities Litigation Reform $\mathrm{Act}^{1}$ amends the federal securities laws ${ }^{2}$ to include a safe harbor for forward-looking ${ }^{3}$ statements. As the stormy history of the legislation indicates, such statements present a contmuing regulatory dilemma. ${ }^{4}$ On the one hand, forward-looking stateinents by issuers $^{5}$ serve an important function in an efficient market. ${ }^{6}$ On

1. Pub. L. No. 104-67, 109 Stat. 737 (1995) [hereinafter Reform Act].

2. In this Note, the term "federal securities laws" refers to the Securities Act of 1933, 15 U.S.C. $\$ \S 77 a-77 a a$ (1994) [hereinafter Securities Act], and the Securities Exchange Act of 1934, 15 U.S.C. $\$ \S 78 \mathrm{a}-78 \mathrm{kk}$ (1994) [hereinafter Exchange Act].

3. Forward-looking information is part of the family of soft information. See Carl W. Schneider, Nits, Grits, and Soft Information in SEC Filings, 121 U. PA. L. REV. 254, 255 (1972). Soft information concerns subjective analysis, as opposed to objectively verifiable historical facts. Id. Forward-looking information refers specifically to different classes of prospective financial information, including projections, predictions, and forecasts. Id. at 258.

4. Prompting the first veto override of the Clinton Administration, the Reform Act was the subject of controversy throughout its passage fron bill into law. See 141 CoNG. REC. H15,214 (daily ed. Dec. 20, 1995).

5. "Issuer" refers to any person who issues or proposes to issue any security. Securities Act, 15 U.S.C. \& 77b(4) (1994). An issuer can be either a coinpany or those persons who control the company. See THOMAS LEE HAZEN, TREATISE ON THE LAW OF SECURTIES REgULATION 468 (2d ed. Supp. 1994).

6. See Roger J. Dennis, Mandatory Disclosure Theory and Management Projections: A Law and Economics Perspective, 46 MD. L. REv. 1197, 1211-18 (1987); Jeffrey N. Gordon \& Lewis A. Kornhanser, Efficient Markets, Costly Information, and Securities Research, 60 N.Y.U. L. REv. 761, 787-88 (1985). Issuers, because they run a business, are best able to interpret historical data and project its implications for the future of that business. See Bart A. Basi et al., A Comparison of the Accuracy of Corporate and Security Analysts, Forecasts of Earnings, 51 ACCT. REv. 244, 252 (1976) (concluding that "there is reasonable evidence that company forecasts were better than analysts' forecasts"); Homer Kripke, The S.E.C., the Accountants, Some Myths and Some Realities, 45 N.Y.U. L. REv. 1151, 1197-99 (1970) (indicating that issuers have access to information and a famil- 
the other hand, forward-looking information is inherently unreliable and prone to mislead investors. ${ }^{7}$ Against the backdrop of a federal securities law regime predicated on disclosure, the Securities and Exchange Commission (SEC) considered forward-looking information so problematic that until 1972 it discouraged disclosure of such information altogether. ${ }^{8}$ While the SEC has reversed its position with regard to whether issuers should disclose forwardlooking information, ${ }^{9}$ SEC safe harbors provide only limited protection to forward-looking statements. ${ }^{10}$ This lack of SEC protection is important to issuers because forward-looking statements that turn out to be wrong ${ }^{11}$ open the door to claims by private litigants against issuers ${ }^{12}$ for material misstatements or omis-

iarity with the workings and prospects for their business that accounting statements alone cannot provide).

7. See Summary of Report on Disclosure to Investors-A Reappraisal of Administrative Policies Under the 1933 and 1934 Acts, [1963-1972 Special Studies Transfer Binder] Fed. Sec. L. Rep. (CCH) II 74,603, at 65,242 (May 9, 1969) ("[P]rojections in filed documents might become traps for the unsophisticated who would be prone to attach more significance to such projections than they deserve."). Issuers may be tempted to make forward-looking statements unduly optimistic, while investors may be overly reliant on such statements. $I d$.

8. See Louis Loss \& Joel SEligman, Fundamentals of SECurities RegulaTION 128 (3d ed. 1995).

9. In the mid-1970s and 1980s, the SEC encouraged the voluntary disclosure of forward-looking information. See Guides for Disclosure of Projections of Future Economic Performance, Securities Act Release No. 5992, [1978 Transfer Binder] Fed. Sec. L. Rep. (CCH) II 81,756, at 81,034 (Nov. 7, 1978). Recently, the SEC has interpreted agency rules to make such disclosure mandatory in certain contexts. In the Matter of Caterpillar Inc., Exchange Act Release No. 30532, [1991-1995 Transfer Binder] Fed. Sec. L. Rep. (CCH) If 73,830, at 63,050 (Mar. 31, 1992) (signaling that SEC intends to vigorously enforce disclosure requirements for forward-looking information). Disclosure of presently known information that will affect future earnings is mandatory under Item 303 of Regulation S-K, while disclosure of pure forecasts is encouraged. Managenent's Discussion and Analysis of Financial Condition and Results of Operations, Securities Act Release No. 6835, 54 Fed. Reg. 22,427 (1989). However, the line separating these two classes of forward-looking information is blurry. See Mark S. Croft, MD\&A: The Tightrope of Disclosure, 45 S.C. L. REV. 477, 484-86 (1994).

10. See infra note 36 and accompanying text.

11. See Whirlpool Fin. Corp. v. GN Holdings, Inc., 873 F. Supp. 111, 121 (N.D. Ill.) (stating that "in an infinitely large universe of honest and careful projections, half will turn out to be too optimistic"), affd, 67 F.3d 605 (7th Cir. 1995).

12. Forward-looking statements also may result in liability for signatories, Securitics Act, 15 U.S.C. $\S 77 \mathrm{k}(1)$ (1994), control persons, Securities Act, 15 U.S.C. $\S 770$ (1994), Exchange Act, 15 U.S.C. $\$ 78 t$ (1994), and others subject to liability under common law principles. However, private rights of action under the federal securities laws for aider and abettor hability, as well as secondary liability under other common law principles, are in doubt after Central Bank of Denver, N.A. v. First Interstate Bank of Denver, N.A., 114 S. Ct. 1439, 1441 (1994). 
sions. ${ }^{13}$ As a result, there is the perception that strike suits ${ }^{14}$ go hand in hand with the disclosure of forward-looking information.

In the void left by the SEC rules, ${ }^{15}$ courts created a form of protection for issuers' forward-looking statements called the "bespeaks caution" doctrine. ${ }^{16}$ The doctrine provides a mechamism for summary judgment or dismissal when issuers provide sufficient cautionary language to qualify forward-looking ${ }^{17}$ stateinents. $^{18}$

13. The relevant sections under which private rights of action for material misstatements or omissions in connection with the offer or sale of securities arise include sections 11 and 12(2) of the Securities Act, 15 U.S.C. $\$ \S 77 k, 77 l(2)$ (1994), and Rule 10b-5, 17 C.F.R. § 240.10b-5 (1995), which was promulgated under section 10(b) of the Exchange Act, 15 U.S.C. $\S 78 \mathrm{j}(\mathrm{b})$ (1994). The elements of a cause of action under section 11 of the Securities Act are a misstatement or omission of a material fact in a registration stateinent in circumstances in which the shares purchased are "traceable to the offering covered by the registration statement." See THOMAS LEE HAZEN, THE LAW OF SECURITIES Regulation 284 (2d ed. 1990). The eleinents of a cause of action under section 12(2) of the Securities Act are a misstatement or omission of a material fact in a prospectus of which the defendant should have known. Id. at 302-04. The elements of a Rule 10b-S cause of action are a misstatement or omission of a material fact, the defendant's knowledge of its falsity and her intention that the plaintiff rely on it, the plaintiff's reasonable rehauce on the representation, and plaintiff's resulting loss. Id. at $666,683-712$.

Forward-looking inforination may appear so subjective as not to be considered "fact." However, most courts hold that disclosure of soft information implies a representation that the information has been formed on a reasonable basis, and such representation is considered a fact within the coverage of sectious 11 and 12(2) of the Securities Act and Rule 10b-S. See Virginia Bankshares, Inc. v. Sandberg, 501 U.S. 1083, 1092-93 (1991) (nnanagement opinion as to fairness of stock price for merger is actionable fact); In re Apple Conputer Sec. Litig., 886 F.2d 1109, 1113 (9th Cir. 1989) ("A projection or statement of belief contains at least three implicit factual assertions: (1) that the statement is genuinely believed, (2) that there is a reasonable basis for that belief, and (3) that the speaker is not aware of any undisclosed facts tending to seriously undermine the accuracy of the statement."), cert. denied, 496 U.S. 943 (1990). But see Barrios v. Paco Pharmaceutical Servs., Inc., 816 F. Supp. 243, 246, 251 (S.D.N.Y. 1993) (stating with respect to projections, referred to in placenent memorandum "only as a nuathematical illustration of the assumptions," that "it is well settled in this and a number of other jurisdictions that future presentations such as contained in the PPM are not statements of material fact on which an investor can rely").

14. "Strike" or "nuisance" suits are suits that have a settlement value based on the expected costs of hitigation, independent of the merits of the claim underlying the suit. See D. Rosenberg \& S. Shavell, A Model in Which Suits Are Brought for Their Nuisance Value, 5 INT'L REV. L. \& ECON. 3 (1985).

15. See infra note 36 and accompanying text.

16. See generally In re Donald J. Trump Casino Sec. Litig., 7 F.3d 357, 371-73 (3d Cir. 1993) (describing bespeaks caution doctrine), cert. denied, 114 S. Ct. 1219 (1994); Donald C. Langevoort, Disclosures That "Bespeak Caution," 49 Bus. LAw. 481 (1994) (same).

17. Beyond forward-looking information, some commentators would expand the doctrine to apply to any soft inforination because soft information does not correlate entirely 
The doctrine also served, in part, as the model for the safe harbor for forward-looking statements by issuers included in the Reform Act. ${ }^{19}$

However, whether an issuer seeks protection under the Reform Act, under the common law bespeaks caution doctrine, or under SEC safe harbors, questions remain as to the nature and extent of cautionary language sufficient to protect issuers making forward-looking statements. Two of these questions relate to defining the "context" in which courts analyze cautionary statements. ${ }^{20}$ Specifically, does the sufficiency of cautionary language depend on (1) who is hearing the cautionary language, or (2) who is speaking? The former question addresses whether a plaintiff's level of sophistication affects the amount of cautionary language necessary to invoke the doctrine. The latter question addresses whether cautionary language can come from sources other than the issuer so as to take into account the total scope of information available to investors. At the present time, the SEC is still formulating a final version of its rules, and the contours of the Reform Act safe harbor have not been fleshed out in litigation. Accordingly, this Note will address questions concerning cautionary language related to forward-looking statements from the perspective of past cases that apply the bespeaks caution doctrine under the federal securities laws prior to the Reform Act. Insofar as the congressional safe harbor and the proposed SEC safe harbor parallel the common law bespeaks caution doctrine, this Note will provide guidance $\mathrm{m}$ their interpretation as well.

Because courts often apply the bespeaks caution doctrine with little discussion of the analytical framework used to actually

with future information. Langevoort, supra note 16, at 489; see also Schneider, supra note 3, at 254-55 (giving examples of soft information). However, courts continue to apply the doctrine only to projections, forecasts, and predictions. See, e.g., Friedman v. Arizona World Nurseries Ltd. Partnership, 730 F. Supp. 521, 539-41 (S.D.N.Y. 1990) (disallowing section $10(\mathrm{~b})$ claim for future expectation statements, but allowing claims for statements regarding then existing facts).

18. Omissions of forward-looking information are similarly protected. See, e.g., In re Trump, 7 F.3d at 371.

19. See Reform Act $\S 102$; see also 141 CONG. Rec. H13,692, at H13,703 (daily ed. Nov. 28, 1995) (joint explanatory statement of the Committee of Conference) ("The Conference Committee safe harbor, like the Senate safe harbor, is based on aspects of SEC Rnle 175 and the judicial created 'bespeaks caution' doctrine.").

20. As stated by the United States Court of Appeals for the Fifth Circuit, "[T]he 'bespeaks caution' doctrine merely reflects the unremarkable proposition that statements must be analyzed in context." Rubinstein v. Collins, 20 F.3d 160, 167 (5th Cir. 1994). 
"weigh" cautionary language, ${ }^{21}$ questions concerning the role of plaintiff sophistication and market information in determming the sufficiency of cautionary language mcrease the uncertainty associated with the disclosure of forward-looking information and diminish protections provided by the doctrine. Similarly, the Reform Act leaves open questions as to the role of plaintiff sophistication and market information in applying the statutory safe harbor. ${ }^{22}$

This Note concludes that plaintiff sophistication and market information should not be considered by courts as part of an analysis of cautionary language under the common law and by extension under the congressional safe harbor. The bespeaks caution doctrine should not encourage parties to misrepresent their opinions in forward-looking statements and then avoid liability by arguing that the plaintiff should have known better because of her sophistication or because information available in the market at large suggests that the investor should have been cautioned. As President Franklin D. Roosevelt stated, "[The Securities Act] adds to the ancient rule of caveat emptor, the further doctrine 'let the seller also beware.' It puts the burden of telling the whole truth on the seller."23 At the saine time, this Note suggests limits that

21. See, e.g., Dulude v. Cigna Sec., Inc., Fed. Sec. L. Rep. (CCH) II 98,324, at 90,244-45 (E.D. Mich. Oct. 5, 1993); Alexander v. Evans, [1993 Transfer Binder] Fed. Sec. L. Rep. (CCH) If 97,795, at 97,904 (S.D.N.Y. Sept. 30, 1993); Schwartz v. Michaels, [1992 Transfer Binder] Fed. Sec. L. Rep. (CCH) If 96,920, at 93,839-40 (S.D.N.Y. July 22, 1992); O’Brien v. National Properiy Analysts Partners, 719 F. Supp. 222, 227 (S.D.N.Y. 1989).

22. Section 102 of the Reform Act states, in pertinent part:

[I]n any private action arising under this title that is based on an untrue statement of a material fact or omission of a material fact necessary to make the statement not misleading, a person ... shall not be liable with respect to any forward-looking statement, whether written or oral, if and to the extent that-(A) the forward-looking statement is-(i) identified as a forward-looking statement, and is accompanied by ineaningful cautionary statements ... or (ii) immaterial .... .

Reform Act $\S 102$ (a) (amending Securities Act $\S 27 \mathrm{~A}(\mathrm{c})(1)$ ). Whether a statement is immaterial sometimes turns on the sophistication of the plaintiff or the scope of information available to the market. See infra text accompanying notes 60-94. Further, there are broad exclusions from application of the Reform Act safe harbor. See Reform Act $\S$ 102(a) (amending Securities Act $\$ 27 \mathrm{~A}(\mathrm{~b})$ ).

Some of the safe harbor provisions do appear to limit cautionary language to that language which comes directly from the issuer, especially with regard to oral forwardlooking statements. See, e.g., id. § 102(a) (amending Securities Act § 27A(c)(2)). To the degree that such cantionary language in the market is excluded from the safe harbor analysis, this accords with the conclusions of this Note.

23. Federal Supervision of Traffic in Investment Securities in Interstate Commerce, 
will benefit issuers making forward-looking statements by creating brighter lines and allowing for greater predictability in the application of the bespeaks caution doctrine or the congressional safe liarbor.

Part I of this Note traces the history and doctrinal foundations of the bespeaks caution doctrine. Part II then describes the extent to which courts have considered plaintiff sophistication and the scope of information available to investors in determining whether issuers have made material misstatements or omissions under the federal securities laws generally. It also describes how courts currently disparately treat these issues im bespeaks caution cases. Part III suggests that courts should determine whether there is sufficient cautionary language to invoke the bespeaks caution doctrine based solely on statements directly attributable to issuers.

\section{HISTORY AND DOCTRINAL FOUNDATION OF THE BESPEAKS CAUTION DOCTRINE}

The common law bespeaks caution doctrine is still bound within the framework of the securities laws passed in the early 1930s. Motivated by the stock market crash of 1929, the securities laws were designed to protect investors. ${ }^{24}$ The Securities Act regulates the initial public offering and sale of securities in interstate commerce. $^{25}$ The Excliange Act provides for the continuing regulation of securities after their initial offering. ${ }^{26}$ When proniulgating the federal securities acts, Congress examined different theories of securities regulation and ultimately chose a "licensing" scheme $^{27}$ that embraced a "fundamental purpose . . to substitute

\footnotetext{
H.R. REP. No. 85, 73d Cong., 1st Sess. 2 (1933).
}

24. See Central Bank of Denver, N.A. v. First Interstate Bank of Denver, N.A., 114 S. Ct. 1439, 1445 (1994); J. ROBERT BRown, JR., THE REgulation OF CORPORATE DISClOSURE 4-5 (supp. 1994); James M. Landis, The Legislative History of the Securities Act of 1933, 28 GEO. WASH. L. REv. 29, 29-30 (1959); Phillip A. Loomis, Jr., The Securities Exchange Act of 1934 and the Investment Advisors Act of 1940, 28 GEO. WASH. L. REv. 214, 216-17 (1960).

25. Unless a statutory exemption is available, section 5 of the Securities Act prohibits the initial offer and sale of unregistered seeurities. 15 U.S.C. $\S \S 77 d, 77 e(a)$ (1994).

26. For an analysis of the SEC's current continuous disclosure system, see JAMES D. CoX et Al., Securtties Regulation: Cases and Materials $46-47$ (1991).

27. Loss \& Seligman, supra note 8 , at 413 . In adopting a system of licensing, Congress declined to approve a regulatory system based on merit review. See Federal Securities Act: Hearing on H.R. 4314 Before the House Comm. on Interstate and Foreign Commerce, 73d Cong., 1st Sess. 53-55, 143-44 (1933). 
a philosophy of full disclosure for the philosophy of caveat emptor and thus to achieve a high standard of business ethics in the securities industry." 28 Accordingly, the securities acts emphasize the proper and timely disclosure of required information. ${ }^{29}$

However, not all information is treated identically under the federal securities laws. The SEC, under its authority pursuant to the Exchange $\mathrm{Act}^{30}$ distinguishes forward-looking information from historical information. ${ }^{31}$ For almost forty years, the SEC regarded forward-looking information too unreliable and misleading to be disclosed. ${ }^{32}$ This policy interfered with the efficient allocation of resources in the marketplace and conflicted with actual market practice. ${ }^{33}$ In 1973 , the SEC announced its intention to promulgate rules to allow voluntary disclosure of projections without liabihty for civil fraud, ${ }^{34}$ which resulted in the creation of safe harbor rules in $1979 .{ }^{35}$ However, the SEC safe harbor rules

28. SEC v. Capital Gains Research Bureau, Inc., 375 U.S. 180, 186 (1963); see also Central Bank of Denver, 114 S. Ct. at 1445; Affiliated Ute Citizens of Utah v. United States, 406 U.S. 128, 151 (1972) (stating philosophy of full disclosure replaced plilosophy of caveat emptor under the securities laws).

29. See, e.g., Pinter v. Dahl, 486 U.S. 622, 638 (1988) (noting that Congress designed disclosure provisions of the Securities Act to protect unsophisticated investors); Santa Fe Indus., Inc. v. Green, 430 U.S. 462, 477-78 (1977) (describing the purpose of the Excliange Act as one of impleinenting a "philosophy of full disclosure"); SECURITIES EXCHANGE BILl of 1934, H.R. ReP. No. 1383, 73d Cong., 2d Sess. 11 (1934) ("[T]le hiding and secreting of important imformation obstructs the operation of the markets as indices of real value.").

30. Exchange Act, 15 U.S.C. § 78d (1994).

31. See supra notes 8-9 and accompanying text.

32. See Guidelines for the Release of Information by Issuers Whose Securities Are in Registration, Securities Act Release No. 5180, [1970-1971 Transfer Binder] Fed. Sec. L. Rep. (CCH) II 78,192, at 80,578-80 (Aug. 16, 1971); Janet E. Kerr, $A$ Walk Through the Circuits: The Duty to Disclose Soft Information, 46 MD. L. REv. 1071, 1073 (1987) ("The SEC's perception of the unreliability of soft information, its potential to mislead investors, and the lack of sufficient Commission resources to evaluate its accuracy quickly negated any benefits flowing froin the disclosure of such information.").

33. See, e.g., Kripke, supra note 6, at 1197-99. Professor Kripke notes that notwithstanding SEC policy, professionals sucl as brokers and analysts would receive management projections informally through press conferences, speecles to analysts' societies, or press releases. Id. at 1199. These projections then would lielp to form the basis for professional judgment. Id.

34. Statement by the Commission on Disclosure of Projections of Future Economic Performance, Securities Act Release No. 5362, [1972-1973 Transfer Binder] Fed. Sec. L. Rep. (CCH) I 79,211 (Feb. 2, 1973).

35. SEC Rule 175, 17 C.F.R. § 230.175 (1994); SEC Rule 3b-6, 17 C.F.R. § 240.3b-6 (1994). Because the rules are virtually identical, this Note refers to all SEC safe luarbors for forward-looking information by reference to Rule 175 . 
for forward-looking statements remain poorly defined and little used. ${ }^{36}$

Until the 1970s, courts also generally refrained from providing any systemic incentives to counter the potential hability associated with forward-looking statements. ${ }^{37}$ In recent years, however, courts have taken a inore proactive role in protecting issuer disclosure in the face of the perceived market-distorting effect of strike suits. ${ }^{38}$ Indeed, there is a growing trend for courts to enter summary judgment ${ }^{39}$ or dismissa $1^{40}$ on issues that were previously

36. See generally Note, Liability for Forward-Looking Statements: The Securities and Exchange Commission's Ambiguous Stance, 1993 COLuM. Bus. L. REv. 221 (1993). While SEC rules insulate soine issuers making forward-looking statements from liability for fraud, the rules apply only to written documents filed with the SEC. 17 C.F.R. $\$ 230.175$ (1994). Further, the safe harbor rules are predicated on an issuer's good faith and reasonable basis for making forward-looking statements. Id. § 230.175(a). The safe harbor rules also may leave issuers with a duty to update their disclosure. See Backnnan v. Polaroid Corp., 910 F.2d 10, 17-18 (1st Cir. 1990) (stating that the duty to update does not apply to matters outside the scope of the imitial disclosure).

The SEC is currently reviewing its safe harbor rules for forward-looking statements. See Safe Harbor for Forward-Looking Statements, Securities Act Release No. 33-7101, 1994 WL 562021 (Oct. 13, 1994) [hereinafter Safe Harbor Release]. One proposed change to the current rules, offered by Professor John Coffee, involves a codification of the common law bespeaks caution doctrine. Id. at $* 23$. This codification, however, would still lack the scope of the common law doctrine. The codification would apply only to forwardlooking statements inade in documents filed with the Commission or to statements made outside the filing requirement that are reaffirmed in a subsequent filing "made publicly available within a reasonable period after the statement is first disseminated." Id. See also Bruce Angiolillo, Bespeaks Caution Doctrine: Heading for Codification?, N.Y. L.J., Jan. 5, 1995, at 1, 6 (describing limits of proposed SEC safe harbor relative to bespeaks caution doctrine).

37. See, e.g., Dolgow v. Anderson, 53 F.R.D. 664, at 686-89 (E.D.N.Y. 1971) (stating that earnings projections can result in Rule $10 \mathrm{~b}-5$ liability if there is no reasonable basis, and that question of reasonable basis is highly fact-specific), aff'd, 464 F.2d 437 (2d Cir. 1972) (per curiain); Bruce A. Hiler, The SEC and the Courts' Approach to Disclosure of Earnings Projections, Asset Appraisals, and Other Soft Information: Old Problems, Changing Views, 46 MD. L. REv. 1114, 1124-31 (1987) (discussing courts' treatment of soft information from 1970 to 1987).

38. See Blue Chip Stamps v. Manor Drug Stores, 421 U.S. 723, 740 (1975) (stating that even a complaint that "by objective standards may have very little chance of success at trial has a settlement value to the plaintiff out of any proportion to its prospect of success at trial").

39. See, e.g., In re Apple Computer Sec. Litig., 886 F.2d 1109, 1116 (9th Cir. 1989) (entering summary judgment when defeudant omitted risks known to market); Laven v. Flanagan, 695 F. Supp. 800, 812 (D.N.J. 1988) (noting decreasing reluctance to grant summary judgment on scienter grounds).

40. See, e.g., Kowal v. MCI Communications Corp., 16 F.3d 1271 (D.C. Cir. 1994) (entering dismissal even though defendant company failed to state that competitive position was deteriorating, that restructuring and merger costs would slow growth, and that coinpetitor placed great pressure on coinpany); Shields v. Citytrust Bancorp, Inc., 25 F.3d 
thought to raise factual questions not subject to judgment on the pleadings. ${ }^{41}$ The bespeaks caution doctrine provides courts with a means to grant dismissal or award summary judgment in such cases.

The term "bespeaks caution" first appeared as dicta in a footnote in the 1977 case of Polin v. Conductron Corp..$^{42}$ The doctrine first served as a ground for summary judgment in Luce $v$. Edelstein. ${ }^{43}$ In Luce, the U.S. Court of Appeals for the Second Circuit held that allegations of intentional misrepresentation regarding statements in an offering memorandum could not survive a motion to dismiss when the memorandum also contained cautionary language directly addressing the statements at issue ${ }^{44}$ After a slow beginning, the doctrine has now mushroomed, ${ }^{45}$ with nine circuits having adopted the doctrine. ${ }^{46}$ Further, the common

1124 (2d Cir. 1994) (dismissing 10b-5 claim in which defendant bank failed to disclose vulnerability of loan portfolio to drop in real estate values).

41. See supra notes 38-40. In addition to deciding issues more aggressively as a matter of law, many courts mcreasingly rely on a variety of other doctrines that make it easier for defendants to obtain summary judgment or dismissal. See Gustafson v. Alloyd Co., 115 S. Ct. 1061, 1072-74 (1995) (holding that section 12(2) of the Securities Act does not extend to secondary market transactions); Central Bank of Denver, N.A. v. First Interstate Bank of Denver, N.A., 114 S. Ct. 1439, 1455 (1994) (holding that no aider and abettor liability in private $10(\mathrm{~b})$ and Rule 10b-5 actions); Pension Benefit Guar. Corp. v. White Consol. Indus., Inc., 998 F.2d 1192, 1196-97 (3d Cir. 1992) (holding that documents outside the pleadings can be considered on motion for summary judgment), cert. denied, 114 S. Ct. 687 (1994); Coffey v. Dean Witter Reynolds Inc., 961 F.2d 922, 927 (10th Cir. 1992) (upholding claim preclusive effect of arbitration awards).

42. 552 F.2d 797 (8th Cir.), cert. denied, 434 U.S. 857 (1977).

43. 802 F.2d 49 (2d Cir. 1986).

44. Id. at 56. Citing Polin, the court held that "[w]e are not inclimed to impose liability on the basis of statements that clearly "bespeak caution." Id.

45. A LEXIS search (Genfed hibrary, Courts file, bespeak! 15 caution, and a subsequent case-by-case search to exclude false positives) found that the bespeaks caution doctrine was cited in less then 10 cases between 1986 and 1988, 30 cases between 1989 and 1991, and 68 cases between 1992 and 1994. More cases citing the doctrine are published every few weeks.

46. See Saltzberg v. TM Sterling/Austin Assoc., Ltd., 45 F.3d 399, 399-400 (11th Cir. 1995); Rubinstein v. Collins, 20 F.3d 160, 167-68 (5th Cir. 1994); In re Worlds of Wonder Inc. Sec. Litig., 35 F.3d 1407, 1415 (9th Cir. 1994), cert. denied, 116 S. Ct. 277 (1995); In re Donald Trump Casmo Sec. Litig., 7 F.3d 357, 371-73 (3d Cir. 1993), cert. denied, 114 S. Ct. 1219 (1994); Abrosino v. Rodman \& Renshaw, Inc., 972 F.2d 776 (7th Cir. 1992); I. Meyer Pincus \& Assoc. v. Oppenheimer \& Co., 936 F.2d 759, 763 (2d Cir. 1991); Moorhead v. Merrill Lynch, Inc., 949 F.2d 243, 245 (8th Cir. 1991); Romani v. Sliearson Lehman Hutton, 929 F.2d 875, 879 (1st Cir. 1991); Sinay v. Lamson \& Sessions Co., 948 F.2d 1037, 1040 (6th Cir. 1991). Some commentators suggest that the Sixth Circuit retreated from the doctrine in Mayer v. Mylod, 988 F.2d 635 (6th Cir. 1993), after the Supreme Court decision in Virginia Bankshares, Inc. v. Sandberg, 501 U.S. 1083 
law doctrine is now, to varying degrees, the basis for both the proposed $\mathrm{SEC}^{47}$ and congressional ${ }^{48}$ safe harbors for forwardlooking information.

Courts applying the bespeaks caution doctrine typically inquire into two separate but related elements of cases in which misrepresentations are made to mvestors: materiality and reasonable reliance. ${ }^{49}$ Under the rubric of "materiahty," cautionary language operates within the total mix of available information to render immaterial otherwise material misrepresentations." Under "reasonable reliance," cautionary language renders possibly misleading statements harmless because an investor could not reasonably rely upon them. ${ }^{51}$ Courts sometimes treat materiality and reasonable reliance interchangeably, ${ }^{52}$ resting the doctrine on one or botll grounds, ${ }^{53}$ or not explicitly stating the grounds upon which they are resting their application of the doctrine. ${ }^{54}$ However, the primciples of materiality and reasonable reliance are not coinpletely interchangeable. Because section 11 and section 12(2) of

(1991). See Angiolillo, supra note 36 , at 5-6 n.23. It appears, however, that the Sixth Circuit has retreated only from applying cautionary language as a per se bar to liability for forward-looking statements. See Mayer, 988 F.2d at 639. The Sixth Circuit stated in Mayer that "Virginia Bankshares contemplates a weighing of the true with the untrue statements in an announcement for liability to result ... Whether the stateinents here were true or false is not an issue to be decided under Rule 12(b)(6)." Id. (emphasis added). Although Virginia Bankshares precluded summary judgunent in Mayer, the court did not foreclose the possibility of application of the bespeaks caution doctrine in other circumstances. Cf. Cione v. Gorr, 843 F. Supp. 1199, 1203-04 (N.D. Ohio 1994) (discussing interaction of Mayer and Virginia Bankshares). The Sixth Circuit has not yet applied the bespeaks caution doctrine in a case after Mayer.

47. See supra note 36.

48. See supra note 19 and accompanying text.

49. See LosS \& SEligman, supra note 8 , at 478 n.172.

50. See infra notes $60-63$ and accoinpanying text.

51. See infra notes $95-97$ and accoinpanying text.

52. See, e.g., Kline v. First Western Gov't Sec., Inc., 24 F.3d 480, 499 (3d Cir.) (Greenberg, J., dissenting) ("I acknowledge that in Trump we held that the cautionary language rendered the alleged misrepresentation immaterial as a natter of law while here we are concerned with whether the plaintiffs reasonably relied on Arvey's opinion letters. But this distinction makes no difference."), cert. denied, 115 S. Ct. 613 (1994).

53. See In re Donald J. Trump Casino Sec. Litig., 7 F.3d 357, 364 (3d Cir. 1993) (holding that bespeaks caution doctrine rests on materiality), cert. denied, $114 \mathrm{~S}$. Ct. 1219 (1994); Sable v. Soutlunark/Envicon Capital Corp., 819 F. Supp. 324, 333, 338 (S.D.N.Y. 1993) (holding that bespeaks caution doctrine rests on reasonable reliance and materiality); Porter v. Shearson Lelıman Bros., Inc., 802 F. Supp. 41, 58 (S.D. Tex. 1992) (holding that bespeaks caution doctrine rests on reasonable reliance).

54. See In re Quarterdeck Office Sys., Inc., Sec. Litig., 854 F. Supp. 1466, 1472 (C.D. Cal. 1994). 
the Securities Act do not require a showing of reasonable reliance, grounding the bespeaks caution doctrine in materiality rather than reasonable reliance expands the number of cases to which the doctrine may potentially be apphed..$^{55}$ Further, since a plaintiff's reasonable reliance may be a subjective determination, the reasonable reliance element-unlike materiality-may open the door to consideration of a plaintiff's sophistication..$^{56}$ Accordingly, the fact that the bespeaks caution doctrine extends logically from both materiality and reasonable reliance does not mean that the doctrine is applied identically when grounded in either element.

\section{MATERIALITY AND REASONABLE RELIANCE VIS-À-VIS PLAINTIFF SOPHISTICATION AND MARKET INFORMATION}

Although the bespeaks caution doctrine is still in a "relatively embryomic state," ary language renders misstatements immaterial, or renders misstatements not subject to being reasonably relied upon, have emerged. Mere boilerplate warnings are insufficient to invoke the doctrine. ${ }^{58}$ Further, warnings or cautionary statements must be specifically connected to the allegedly misleading forward-looking statements and relevant within the context of the statements as a whole. ${ }^{59}$ These guidelines, however, do not provide much guidance in defining the elusive concepts of materiahty and reasonable reliance. For example, it remains unclear whether courts applying the bespeaks caution doctrine consider plaintiff sophistication or

55. See supra note 13.

56. See infra notes 98-102 and accompanying text (discussing courts' application of subjective reasonable reliance test).

57. Langevoort, supra note 16 , at 488.

58. See, e.g., Huddleston v. Herman \& MacLean, 640 F.2d 534, 543-44 (5th Cir. 1981), modified, 459 U.S. 375 (1983). But see Schwartz v. Michaels, [1992 Transfer Binder] Fed. Sec. L. Rep. (CCH) I 96,920, at 93,840 (S.D.N.Y. July 22, 1992) (dismissing allegations that forecasts in private placement memorandum accompanied by cautionary language were "manipulated").

59. See Rubinstein v. Collins, 20 F.3d 160, 168 (5th Cir. 1994). For example, one cannot have generalized warnings in conjunction with very specific predictions. See Whirlpool Fin. Corp. v. GN Holdings, Inc., 67 F.3d 605 (7th Cir. 1995); In re Marion Merrell Dow Inc., Sec. Litig., [1993 Transfer Binder] Fed. Sec. L. Rep. (CCH) II 97,776, at 97,768-69 (W.D. Mo. 1993) (holding cautionary language not "repeated" and "specific" enough to justify dismissal); In re Jenny Craig Sec. Litig., [1992-1993 Transfer Binder] Fed. Sec. L. Rep. (CCH) If 97,337, at 95,723 (S.D. Cal. 1992) (holding cautionary statements "too weak and too general to counter-balance [defendants'] statements of optimism"). 
market information in determining whether misstatements or omissions by issuers are material or subject to a plaintiff's reasonable reliance.

\section{A. Materiality}

The antifraud provisions of the federal securities laws only prohibit material misrepresentations or omissions of fact, not inere inaccuracies. ${ }^{60}$ In TSC Industries, Inc. $v$. Northway Inc. ${ }^{61}$ the Supreme Court held that a statement is material if there is "a substantial likelihood that [its] disclosure ... would have been viewed by the reasonable imvestor as having sigmificantly altered the 'total mix' of information made available." be such that it would actually change the reasonable investor's investinent decision. ${ }^{63}$

There is some uncertainty concerning what information would "significantly alter the total mix of information" in the context of forward-looking information. ${ }^{64}$ The general rule applied to determine whether there is a substantial hikelihood that forward-looking or other soft information would significantly alter an investor's view is based on a "balancing of both the indicated probability that the event will occur and the anticipated magnitude of the event in light of the totality of the company activity." some courts have limited the Basic Inc. v. Levinson "probability/maguitude test" for materiality to the context of merger negoti-

60. See, e.g., Acme Propane, Inc. v. Tenexco, Inc., 844 F.2d 1317, 1321 (7th Cir. 1988) ("First, only 'material' misstatements permit recovery under the securities laws ....").

61. 426 U.S. 438 (1976).

62. Id. at 449. The TSC standard is higher than the Seventh Circuit's suggested "might" standard. Northway Inc. v. TSC Indus., Inc., 512 F.2d 324, 330 (7th Cir. 1975) (holding that material facts include "all facts which a reasonable shareholder might consider important"). While TSC involved the omission of a fact in a proxy solicitation, the Supreme Court's holding in the case has been widely applied. See, e.g., Flamm v. Eberstadt, 814 F.2d 1169, 1174 (7th Cir. 1987) ("[L]ike every other court of appeals we have taken the definition [of materiality] in TSC as suitable for the term wherever it appears in securities law."), cert. denied, 484 U.S. 853 (1987).

63. TSC, 426 U.S. at 448.

64. See Hiler, supra note 37, at 1172-95 (describing the different approaches of U.S. courts of appeals to defining inateriality of soft information).

65. Basic Inc. v. Levinson, 485 U.S. 224, 238 (1988) (quoting SEC v. Texas Gulf Sulphur Co., 401 F.2d 833, 849 (2d Cir. 1968)); see also Hiler, supra note 37, at 1195 (supporting "probability/magnitude test" for determming materiality of forward-looking statements). 
ations, and in other contexts inquire into the rehability of the forward-looking information in question. ${ }^{66}$ Regardless of which test is applied, determining the materiality of statements or omissions is highly fact-specific and remains so by design. ${ }^{67}$ In addition, regardless of which test is applied, courts determine materiality based upon an objective reasonable-investor standard. ${ }^{68}$ Accordingly, no bespeaks caution cases inquire into plaintiff sophistication when materiality is the sole ground on which the doctrine is predicated. ${ }^{69}$

While the leading case applying the bespeaks caution doctrine, In re Donald J. Trump Securities Litigation," states that "when an offering document's forecasts, opinions or projections are $a c$ companied by meaningful cautionary statements, the forward-looking statements will not forn the basis for a securities fraud claim," "71 courts sometimes inquire imto information about an issuer disclosed by sources other than the issuer to qualify material misstatements or omissions under the bespeaks caution doctrine. In bespeaks-caution-doctrine cases, courts generally import the analysis applied in cases outside the context of the doctrine addressing the issue of what publicly available information is to be

66. See, e.g., Garcia v. Cordova, 930 F.2d 826, 829-30 (10th Cir. 1991) (holding that the information at issue was too unreliable to be considered a material fact).

67. See House COMm. ON INTERSTATE AND FOREIGN COMMERCE, 95TH CONG., 1ST SESS., REPORT OF THE ADVISORY COMM. ON CORPORATE DisClOSURE TO THE SECURITIES AND EXCHANGE Commission (Comm. Print 1977).

Although the Committee believes that ideally it would be desirable to have absolute certainty in the application of the materiality concept, it is its view that such a goal is illusory and unrealistic. The materiality concept is judgmental in nature and it is not possible to translate this into a numerical formula. The Committee's advice to the [SEC] is to avoid this quest for certainty and to continue consideration of materiality on a case-by-case basis as disclosure problems are identified.

Id. at 327.

68. TSC Indus., Inc. v. Northway Inc., 426 U.S. 438, 445 (1976). However, Edward C. Fletcher III suggests that the ostensibly objective materiality test in TSC may at times he treated as a subjective rule in Rule 10(b)-5 cases. Edward C. Fletcher III, Sophisticated Investors Under the Federal Securities Laws, 1988 DUKE L.J. 1081, 1097-98. Professor Fletcher argues that TSC is distinguishable because it involved a proxy solicitation. Id. at 1099. Further, even when treated as an objective standard, some courts implicitly recognize plaintiff sophistication in the materiality analysis. Id. at 1098.

69. See In re Donald J. Trump Casino Sec. Litig., 7 F.3d 357, 369 (3d Cir. 1993) (applying TSC objective reasonable investor test to determine inateriality), cert. denicd, 114 S. Ct. 1219 (1994).

70. Id.

71. Id. at 371 (emphasis added). 
considered part of the "total mix" of information available to investors. ${ }^{72}$ Some guidelines have emerged from these non-bespeaks caution doctrine cases that address the question of what information goes into the total mix: Offering documents that plaintiffs receive, even if only constructively, are part of the total mix; ${ }^{73}$ other documents filed with the SEC, such as the annual or quarterly filings, ${ }^{74}$ also are generally part of the total mix. ${ }^{75}$ Some courts have held that information known to the market about an industry in general may be considered part of the total mix of information to determine materiality. ${ }^{76}$ In other words, issuers have a duty to disclose only firm-specific information. For example, in Wielgos v. Commonwealth Edison Co. ${ }^{77}$ the Seventh Circuit held that Commonwealth Edison need not disclose the possibility that a branch of the Nuclear Regulatory Commission could deny the company's new plant an operating perinit. ${ }^{78}$ However, it is not always clear when information is firm-specific and when it concerns an industry in general. ${ }^{79}$ Further, courts recognize that

72. See Rubinstein v. Collins, 20 F.3d 160, 167-68 (5th Cir. 1994); In re Valuevision Int'1 Sec. Litig., 1995 WL 490476 (E.D. Pa. Aug. 11, 1995); cf. BRowN, supra note 24, at 135 ("Whatever the reason, the total mix doctrine remains undeveloped. Courts seem guided as much by common sense rather than any comprehensive understanding of the doctrine.").

73. Courts uniformly consider offering documents, mcluding proxy statements, tender offer stateinents, and registration statements, designed to significantly affect investors' decisions, and are therefore material under the TSC standard. See Loss \& SELIGMAN supra note 8 , at $474-77$.

74. See, e.g., Form 10-K, 17 C.F.R. § 249.310 (1995) (annual report); Form 10-Q, 17 C.F.R. § 249.308a (1995) (quarterly report); Form 8-K, 17 C.F.R. § 249.308 (1995) (required after occurrence of certain specified events to keep filing information current).

75. See Shamrock Holdings, Inc. v. Polaroid Corp., 709 F. Supp. 1311, 1322 (D. Del. 1989) (holding that past annual reports are part of the total mix of information); Alizac Partners v. Rospatch Corp., 712 F. Supp. 599, 607-608 (W.D. Mich. 1989) (holding that a company's past annual and quarterly reports may be viewed as part of the total mix of information available to shareholders). But see United Paperworkers Int'l Union v. International Paper Co., 985 F.2d 1190, 1200 (2d Cir. 1993) (holding that documents filed with the SEC are excluded from the total mix when considering the materiality of misstatements and omissions in proxy materials).

76. See infra notes 84-87 and accompanying text.

77. 892 F.2d 509 (7th Cir. 1989)

78. Id at 515. The court stated that "[i]ssuers need not 'disclose' Murphy's Law or the Peter Principle, even though these have substantial effects on business. So too issuers need not estimate the chance that a federal agency will change its rules or tighten up on enforcement." Id.; see also B.L. Sailors v. Northern States Power Co., 4 F.3d 610, 612 (8th Cir. 1993) (holding that after informing investors that it is involved in a regulatory proceeding, a utility has no duty to disclose that efforts to obtain a rate increase were "highly problematical").

79. See In re Bally Mfg. Sec. Corp. Litig., 141 F.R.D. 262, 272 (N.D. Ill. 1992) (hold- 
the significance of information in the public domain may be lost on investors. ${ }^{80}$ In Wechsler $v$. Steinberg, ${ }^{81}$ for example, the court declined to dismiss plaintiffs' claim in which the defendant's annual report omitted certain contingent habilities, even though other public sources contained the relevant facts. ${ }^{82}$ The court refused to grant summary judgment, notimg the possibility that, as the plaintiffs argued, the offering materials were "so fragmented as to inhibit comprehension." 83

Beyond information known about an industry in general, some courts assume that firm-specific information disclosed by sources other than the issuer, or issuer disclosure in documents not filed with the SEC, is in the market and universally available. ${ }^{84}$ This broad definition of the total mix accords with the efficient capital market hypothesis. ${ }^{85}$ The efficient capital narket hypothesis suggests that once information enters the market it is quickly impounded and reflected in stock price. ${ }^{86}$ However, recognizing that markets are not always efficient, courts have not been willing to extend the fraud-on-the-market doctrine to thinly traded securities. ${ }^{87}$ Further, the corollary truth-on-the-market de-

ing that it is a mixed question of law and fact whether particular information was firmspecific), aff'd sub nom. Arazie v. Mullane, 2 F.3d 1456 (7th Cir. 1993).

80. See, e.g., McMahon \& Co. v. Wherehouse Entertainment Inc., 900 F.2d 576, 579 (2d Cir. 1990) (finding that information that is actually accurate can mislead investors through manner of presentation), cert. denied, 501 U.S. 1249 (1991).

81. [1975-1976 Transfer Binder] Fed. Sec. L. Rep. (CCH) II 95,449 (E.D.N.Y. Feb. $13,1976)$.

82. Id. at 99,276 .

83. Id. at $99,275-76$ (holding that confiict between plaintiffs' and defendants' arguments raised genuine issues of fact that precluded summary judgment).

84. See HAZEN, supra note 5, at 489.

85. See Roger J. Dennis, Materiality and the Efficient Capital Market Model: A Recipe for the Total Mix, 25 WM. \& MARY L. REv. 373, 419 (1984) (comparing the legal concept of materiality with efficient capital market theory and concluding that the efficient market model "guaranties the total mix concept").

86. Based on the efficient capital market hypothesis, the Supreme Court in Basic Inc. v. Levinson, 485 U.S. 224 (1988), recognized the fraud-on-the-market theory. The Court held that it is not inappropriate to apply a rebuttable presumption of reliance and materiahty - that is, misstatements or omissions that cause a change in a stock's price are material-if plaintiffs can show that their purchase of stock after a material misstatement or omission caused an adverse reaction in the stock's price, even if the plaintiffs in question did not directly hear the statement. $I d$. at 249-50.

87. In Alter v. DBLKM, Inc., 840 F. Supp. 799, 804 (D. Colo. 1993), the court held that for the fraud-on-the-market doctrine to apply, the following conditions must be satisfied: (1) the security must have traded in large volune during the time period in question; (2) a significant number of securities' analysts must have followed and reported on 
fense ${ }^{88}$ recognizes that information from different sources conveyed by different means may be weighed differently by the market. $^{89}$ Accordingly, some courts reject applying market information to the bespeaks caution inquiry because of the fact-specific nature of the efficient market analysis, and the weight to which investors and analysts give forward-looking statements by issuers. ${ }^{90}$

In cases involving the bespeaks caution doctrine, whether a court will consider market information when determining the sufficiency of cautionary language may turn on the plaintiff's underlying cause of action. For example, in Pache v. Wallace ${ }^{91}$ the court held that plaintiffs' reliance on a fraud-on-the-market theory opened the door to consideration of market information by the court in determining the sufficiency of cautionary language under the bespeaks caution doctrine. ${ }^{22}$ However, other courts include inarket information in the bespeaks-caution-doctrine analysis regardless of the underlying cause of action. For example, the court in Heil v. Lebow ${ }^{93}$ did not use the plaintiffs' fraud-on-the-market claim as a predicate for considering market information in deter-

the security; and (3) the price of the security must have changed in relation to public statements or reports about the activities of the issuer.

88. In In re Apple Computer Sec. Litig., 886 F.2d 1109, 1119 (9th Cir. 1989), cert. denied, 496 U.S. 943 (1990), the Ninth Circuit held that extensive media coverage of the risks associated with a new product, even in the same articles in which the company was touting the product, meant that the company's alleged failure to disclose the risks did not violate Rule $10 \mathrm{~b}-5$.

89. As stated by the Ninth Circuit, failure to disclose material information may be excused only when that information has "credibly entered the market by other means" and been couveyed with "roughly equal intensity and credibility." In re Apple, 886 F.2d at 1114. This ruling has the practical effect of limiting the truth-on-the-market defense.

90. See, e.g., Trafton v. Deacon Barclays de Zoete Wedd Ltd. [1994-1995 Decisions Binder] Fed. Sec. L. Rep. II 98,481, at 91,290 (N.D. Cal. Oct. 19. 1994) (holding that cautionary language in only one of several offering documeuts precludes dismissal under the bespeaks cautiou doctrine).

91. [Current] Fed. Sec. L. Rep. I 98,643, at 91,964 (E.D. Pa. March 20, 1995).

92. Id. at 91,969 .

93. [1994-1995 Decision Binder] Fed. Sec. L. Rep. I 98,465, at 91,189 (S.D.N.Y. Nov. 14, 1994). 
mining the sufficiency of cautionary language. ${ }^{94}$ No court has noted this apparent sphit of authority.

\section{B. Reasonable Reliance}

Plaintiffs bringing claims under section 10(b) of the Exchange Act and Rule 10b-5 alleging that an issuer has made a material misstatement must show reasonable rehance ${ }^{95}$ on the alleged misstatement, not merely that the misstatement was inaterial. ${ }^{96}$ Whether an investor has reasonably relied is a determination based on a factors test. ${ }^{97}$ The certainty of a factors test is somewhat chimerical because there is no formula for weighing each of the various factors and no necessary and sufficient factor for determining when the reasonable investor slould not have relied on a misstatement or omission. Like inateriality, therefore, reasonable reliance lends itself to categorization as a determination of fact.

Whether a court will inquire into plaintiff sophistication under the bespeaks caution doctrine when determining reasonable reliance unay turn on the factual circumstances underlying the cause of action. While the majority of courts nominally recognize a subjective reasonable-reliance standard, ${ }^{98}$ this general rule is limit-

94. Id.; see also Kaplan v. Kahn, [1994-1995 Decision Binder] Fed. Sec. L. Rep. II 98,486, at 91,322 (N.D. Cal. Oct. 25, 1994) ("Based on the holdings of [the Ninth Circuit in In re Worlds of Wonder Securities Litigation, 35 F.3d 1407 (9th Cir. 1994)], and the cases that have preceded it, there are two levels to the bespeaks caution analysis . . . (2) the language inust be analyzed in the context of information known to the market at the time of the offering.").

95. Reasonable rehiance is sometimes discussed in terms of justifiable reliance, reasonable diligence, due diligence, or duty of care. See Margaret V. Sachs, The Relevance of Tort Law Doctrines to Rule 10b-5: Should Careless Plaintiffs Be Denied Recovery?, 71 CORNELl L. REV. 96, 102-03 (1985). Most courts and commentators view these terms as basically interchangeable. See id; Note, Reliance Under Rule 10b-5: Is the 'Reasonable Investor' Reasonable?, 72 COLUM. L. REv. 562 (1972). But see Huddleston v. Herman \& Maclean, 640 F.2d 534, 548 (5th Cir. 1981) (holding that reasonable reliance is a subjective test, while justifiable reliance is an objective test), aff'd in part, rev'd in part, 459 U.S. 375 (1983).

96. Reasonable reliance is not an element of claims under section 11 and section 12(2) of the Securies Act. See supra note 13.

97. These factors include (1) the sophistication or expertise of the investor in financial and securities matters; (2) the existence of longstanding business or personal relationslips; (3) access to the relevant information; (4) the existence of a fiduciary relationship; (5) concealment of the fraud; (6) opportunity to detect the fraud; (7) whether the investigator initiated or sought to expedite the transaction; and (8) the generality or specificity of the inisrepresentations. Molecular Technology Corp. v. Valentine, 925 F.2d 910, 918 (6th Cir. 1991).

98. See, e.g., Davidson v. Wilson, 973 F.2d 1391, 1400 (8th Cir. 1992); Molecular 
ed by presumptions of reasonableness that are applied in various contexts. The principal limiting presumption occurs in class actions, in which courts apply the equivalent of an objective reasonableness standard, at least at the pleading stage. ${ }^{99}$ Therefore, courts actually apply a subjective reasonable reliance test only in cases involving private placement memorandums, close corporations, and customer-broker relations. ${ }^{100}$ The original body of cases in which courts applied the bespeaks caution doctrine involved private placement meinorandums, ${ }^{101}$ but even in these cases, an essentially objective reasonable-reliance standard is applied in the case of misleading omissions. ${ }^{102}$

As is true in cases in which courts base the bespeaks caution doctrine on materiality, courts have inquired into the "total mix" of infornation available in determining whether an investor has reasonably relied on issuers' misstatements or omissions. ${ }^{103}$ Indeed, the fraud-on-the-market theory creates a presumption of both reliance and materiality, and the question of whether courts consider market infornation in order to rebut the presumption of reliance parallels the question as applied to the element of materiality. ${ }^{104}$ As with materiality, there is no clear rule as to when and if market information may be used to determine the reasonableness of a plaintiff's reliance. Nor is it clear that courts always

Technology Corp. v. Valentine, 925 F.2d 910, 918 (6th Cir. 1991); Myers v. Finkle, 950 F.2d 165, 167 (4th Cir. 1991); Royal Am. Managers, Inc. v. IRC Holding Corp., 885 F.2d 1011, 1015-16 (2d Cir. 1989); Kennedy v. Josephthal \& Co., Inc., 814 F.2d 798, 804 (1st Cir. 1987); Zobrist v. Coal-X, Inc., 708 F.2d 1511, 1516 (10th Cir. 1983). But see In re Olympia Brewing Co. Sec. Litig., 674 F. Supp. 597, 622 (N.D. Ill. 1987) (rejecting defendant's argninent that sophisticated customers are bound by indemnity agreement).

99. See, e.g., In re Western Union Sec. Litig., 120 F.R.D. 629, 633-34 (D.N.J. 1988).

100. See, e.g., Clayton Brokerage Co. of St. Louis, Inc. v. CFTC, 794 F.2d 573, 578-79 (11th Cir. 1986) (customer-broker relations); Sharp v. Coopers \& Lybrand, 649 F.2d 175, 185, 189 (3d Cir. 1981), cert. denied, 455 U.S. 938 (1982) (close corporation); Swenson v. Engelstad, 626 F.2d 421, 427-28 (5th Cir. 1980) (private placement memorandum).

101. See, e.g., Sable v. Southmark/Envicon Capital Corp., 819 F. Supp. 324, 334 (S.D.N.Y. 1993); Schwartz v. Michaels, No. 91 Civ. 3538 (RPD), 1992 WL 184527, at *9 (S.D.N.Y. July 23, 1992).

102. See Basic Inc. v. Levinson, 485 U.S. 224, 241-50 (1988). Basic leads to a rebuttable presumption of reliance in cases of misleading omissions. Id. This presumption results in the application of an objective standard of reliance because each plaintiff need not demonstrate actual reliance. $I d$. at 245 . Indeed, when nondisclosure is involved, proving reliance may border on the impossible absent a presumption.

103. See Rubinstein v. Collins, 20 F.3d 160, $167-69$ (5th Cir. 1994); Whirlpool Fin. Corp. v. GN Holdings, Inc., 873 F. Supp. 111, 122 (N.D. Ill. 1995), affd, 67 F.3d 605 (7th Cir. 1995).

104. See supra notes 70-94 and accompanying text. 
require that plaintiffs plead the fraud-on-the-market theory before courts will consider market information when determining reasonableness of reliance. ${ }^{105}$ Some of the factors considered in the eight-part factors test, ${ }^{106}$ including "access to relevant information,"107 suggest that inquiry nito market information is a necessary condition for determining reasonable rehance. On the other hand, courts are sometimes reluctant to consider narket information when considering reasonableness of reliance under the bespeaks caution doctrime because it complicates the already highly factual reasonable-reliance-factors test. ${ }^{108}$ In practice, therefore, courts inquire into market information when determining reasonable rehance under the bespeaks caution doctrine witl the same level of unpredictability as when inquiring into the materiality of alleged misstateinents or omissions.

105. Compare In re Apple Computer Sec. Litig., 886 F.2d 1109, 1114 (9th Cir. 1989) ("Where a plaintiff alleges actual reliance on a particular statement, it does not matter that the market is aware of the facts necessary to make the statement not misleading. The plaintiff may be misled into believing that the stock has been mcorrectly valued by the market."), cert. denied, 496 U.S. 943 (1990), with Harner v. Prudential Sec., Inc., 785 F. Supp. 626 (E.D. Micl. 1992), aff'd 35 F.3d 565 (6th Cir. 1994) (considering market information wlien determining reasonable reliance even absent fraud-on-the-market claim) and Levy v. Weksel, No. 85 Civ. 0990 (VLB), 1995 WL 117637, at *2 (S.D.N.Y. Mar. 17, 1995) (same).

106. See supra note 97.

107. Id.

108. For example, the court in Duke v. Touche Ross \& Co., 765 F. Snpp. 69 (S.D.N.Y. 1991), lield that it is not sufficient to prevail on a motion for judgment on the pleadings to merely point out cautionary language in a private placement memorandum. Id. at 74. The court stated that it is a question of fact whether investors could justifiably rely on the alleged misstatements. Id. Similarly, the fact-specific nature of determining materiality las led courts to restrain their application of the bespeaks caution doctrine. See, e.g., Trafton v. Deacon Barclays De Zoete Wedd Ltd., 1994 WL 746199 (N.D. Cal. Oct. 19, 1994) (liolding that cautionary language was insufficient to lead to summary judgment, but could be considered at trial with respect to the question of materiality). Indeed, determining the efficiency of the market, the theoretical predicate for considering market information, is itself a fact-specific determination. See Garfinkel v. Memory Metals, Inc., 695 F. Supp. 1397, 1403-04 (D. Conn. 1988). Similarly, determining plaintiff sophistication may be fact-specific, as wealth alone is not determmative. $C f$. SEC v. Ralston Purina Co., 346 U.S. 119, 126-27 (1953) (liolding that nonpublic offering exemption from Securities Act registration requirements is predicated on access to information, not status of investor). 


\section{REFining the BESPEAKS CAUTION DOCTRINE}

The Supreme Court has indicated that the intent of Congress governs the interpretation of the elements of actions under the federal securities laws. ${ }^{109}$ Factors to be considered in determining congressional intent include the language and history of the statutory provision in question ${ }^{110}$ and the structure of the Securities Act and Exchange Act. ${ }^{111}$ Courts also may be guided by the language of administrative rules and the rulemaking history surroundmg their adoption. ${ }^{112}$ When the language and structure of a statute and congressional intent are not determinative, courts must look to the policies underlying the statute in question. ${ }^{113}$

\section{A. Courts Should Not Consider Plaintiff Sophistication When De- termining the Sufficiency of Cautionary Language}

The language and structure of the securities laws do not reveal Congress's intent in defining the role of plaintiff sophistication im bespeaks caution cases. Whether courts should inquire into each plaintiff's sophistication under Rule $10 \mathrm{~b}-5^{114}$ cannot be determined from the explicit language of the federal securities laws. ${ }^{115}$ Indeed, controversy exists about the degree to which the federal securities laws were designed to account for investor sophistication at all. ${ }^{116}$ The securities laws generally make no mention of plaintiff sophistication. ${ }^{117}$ Commentators lave suggested

109. See Central Bank of Denver, N.A. v. First Interstate Bank of Denver, N.A., 114 S. Ct. 1439, 1447 (1994).

110. See Pinter v. Dahl, 486 U.S. 622,652 (1988) (stating that specific language of statutes controls interpretation based on policy).

111. Central Bank of Denver, 114 S. Ct. at 1441-42.

112. See, e.g., Blue Chip Stamps v. Manor Drug Stores, 421 U.S. 723, $748-49$ (1975).

113. See, e.g., Bateman Eichler, Hill Richards, Inc. v. Berner, 472 U.S. 299, 314 (1985).

114. Sections 11 and $12(2)$ of the Securities Act, 15 U.S.C. $\S \S 77 \mathrm{k}, 771(2)$ (1994), do not include a reasonable rehance element, and materiality does not include an inquiry into plaintiff sophistication. See supra note 13.

115. See Sachs, supra note 95, at 117 ("[N]othing in section 10(b) suggests that a defendant might avoid liability because of the victim's carelessness."); see also Donald C. Langevoort, Rule $10 b-5$ as an Adaptive Organism, 61 FORDHAM L. REV. S7 (1993) (noting flexibihity and open-ended language of Rule 10b-5).

116. See generally Fletcher, supra note 68, at 1099.

117. Id. The definition of accredited investor in section 2(15) of the 1933 Securities Act, 15 U.S.C. $\S 77 \mathrm{~b}(15)$ (1994), is a notable exccption to the general lack of regard for plaintiff sophistication. However, accreditation is relevant to only a few sections of the securities laws. See Securities Act $\S 4(6), 15$ U.S.C. $\S 77 \mathrm{~d}(6)$ (1994) (sales to accredited 
that the structure of the Exchange Act ${ }^{118}$ argues against the application of differing standards based on plaintiff sophistication. ${ }^{119}$ Because the statutory language is not determinative, courts look to the legislative history of the securities laws to guide interpretation of the provision in question. ${ }^{120}$ The legislative history, however, is similarly uninstructive. ${ }^{121}$

The public policy goals explicitly embodied in the federal securities laws cannot be reconciled with inquiry imto plaintiff sophistication when applying the bespeaks caution doctrine. The overwhelming thrust of the securities laws is the protection of investors. ${ }^{122}$ Most imquiries into plaintiff sophistication, however, benefit issuers. ${ }^{123}$ In each case in which a court has considered an individual investor's sophistication in applying the bespeaks caution doctrine, the court has ultimately granted defendants summary judgment or dismissal. ${ }^{124}$

investors exception to 1933 Act registration requirements). Investor sophistication also is considered a factor in determining whether there has been a nonpublic offering of securities under section 4(2) of the Securities Act, 15 U.S.C. $\$ 77 d(2)$. See SEC v. Ralston Purina Co., 346 U.S. 119 (1953).

118. In addition to comparing related laws, determining statutory structure involves coinparing the language and express remedies within the Act as a whole. See Sachs, supra note 95 , at 121 .

119. See, e.g., id. at 121-29 (critiquing method of interpretation based on statutory structure, specifically with reference to plaintiff sophistication under the Exchange Act).

120. Pinter v. Dahl, 486 U.S. 622, 652 (1988).

121. See Ernst \& Ernst v. Hochfelder, 425 U.S. 185, 201 (1976) (The legislative history surrounding section $10(\mathrm{~b})$ is "bereft of any explicit explanation of Congress' intent."); Steve Thel, The Original Conception of Section 10(b) of the Securities Exchange Act, 42 STAN. L. REV. 385, 385 (1990) ("Section 10 (b) is seldom mentioned in the committee reports, floor statements and published hearings on the Exchange Act . . . .").

122. See, e.g., Affiliated Ute Citizens v. United States, 406 U.S. 128, 150-51 (1972) ("The Court has said that the 1934 Act and its companion legislative enactments embrace a 'fundamental purpose . . . to substitute a philosophy of full disclosure for the philosophy of caveat emptor." (quoting SEC v. Capital Gains Research Bureau, 375 U.S. 180, 186 (1963))).

123. See, e.g., Fletcher, supra note 68, at 1095.

124. See, e.g., Sable v. Southmark/Envicon Capital Corp., 819 F. Supp. 324 (S.D.N.Y. 1993); Harner v. Prudential Sec. Inc., 785 F. Supp. 626 (E.D. Mich. 1992), affd, 35 F.3d 565 (6th Cir. 1994); Hottinger v. Amcoal Energy Corp., 89 Civ. 6391, 1992 WL 349851, at *5 (S.D.N.Y. Nov. 10, 1992); Adler v. Berg Hannon Assocs., 790 F. Supp. 1222 (S.D.N.Y. 1992); Shochat v. Weisz, 797 F. Supp. 1097 (E.D.N.Y. 1992); Schwartz v. Michaels, [1992 Transfer Binder] Fed. Sec. L. Rep. (CCH) II 96,920 (S.D.N.Y. July 22, 1992); Haggerty v. Comstock Gold Co., 765 F. Supp. 111 (S.D.N.Y. 1991); see also Jackson Nat'l Life Ins. Co. v. Merrill Lynch \& Co., Inc., [1993-94 Transfer Binder] Fed. Sec. L. Rep. (CCH) II 98,058 (S.D.N.Y. Nov. 8, 1993), aff d, 32 F.3d 697 (2d Cir. 1994) (using plaintiff sophistication factor in detennining when plaintiffs were on mquiry notice leading 
While inquiry into plaintiff sophistication could argue for the necessity of more cautionary language if an investor is unsophisticated, courts generally do not inquire into plaintiff sophistication to protect investors. ${ }^{125}$ Courts note that in an institutionalized market, investors, no matter their sophistication, receive statements about an issuer primarily through the filter of market intermediaries. ${ }^{126}$ Further, accounting for a lack of plaintiff sophistication could work contrary to its purposes and result in a flood of information, mcreasing the costs of capital formation and resulting in a net loss for investors. ${ }^{127}$

Because inquiry into plaintiff sophistication as part of a reasonable-rehance analysis is a one-way street in favor of issuers, it dilutes the deterrence value of the antifraud rules and provides a defense for otherwise culpable defendants. For example, the court in Hottinger v. Amcoal Energy Corp. ${ }^{128}$ dismissed the plaintiffs' section 10(b) complaint without addressing the defendant's allegedly fraudulent misstatements and oinissions. Through private placements, the defendant, Ancoal, sold limited partnerships in coal mines that operated as investment tax shelters. ${ }^{129}$ The plaintiffs alleged that the defendants did not apply any of the proceeds from the placement towards developing mines, and that the defendants deliberately and systematically misapphed investor funds. ${ }^{130}$ It is unclear whether these claims had any merit because the court summarily dismissed the case, statimg that "[c]autionary language

to statute of limitations and, on an alternate ground, applying the bespeaks caution doctrine).

125. In re Westinghouse Sec. Litig., 832 F. Supp. 948, 976 (W.D. Pa. 1993) (denying plaintiff argument that plaintiff's lack of sophistication requires iucreased cautionary language). Lack of sophistication appears to protect investors only in customer-broker relation cases. See Loss \& SELIGMAN, supra note 8, at 896-902. Brokers, however, are not in a position to issue the soft information that the bespeaks caution doctrine is designed to protect.

126. See Loss \& SELIGMAN, supra note 8, at 128-29; In re Westinghouse, $832 \mathrm{~F}$. Supp. at 976. But see Joel Seligman, Another Unspecial Study: The SEC's Market 2000 Report and Competitive Developments in the United States Capital Markets, 50 BUs. LAW. 485, 490-91 (1995) (While institutionalized investors may comprise an imcreasingly large percentage of the capital inarkets, the raw number of individual investors continues to increase.).

127. See Basic Inc. v. Levinson, 485 U.S. 224, 231 (1988); TSC Indus., Inc. v. Northway, Inc., 426 U.S. 438, 448-49 (1976).

128. 89 Civ. 6391 (LLM), 1992 WL 349851 (S.D.N.Y. Nov. 10, 1992).

129. Id. at *1. The defendants allegedly projected that "year-end tax deductions [would be] equal to roughly three times [the investors'] initial cash investment." Id.

130. Id. 
shows that plaintiff, a highly sophisticated investor, should have appreciated that there were significant risks associated with the placement ...."131

Similarly, in Hayden v. Feldman ${ }^{132}$ the court dismissed the plaintiffs' claims without addressing the alleged fraud of the defendants. In Hayden, defendants were selling limited partnerships in which each of the general partners would act as commodities broker-dealers who traded primarily in metals and government-backed securities. The defendants represented that the plamtiffs would be entitled to declare their share of the partnership's profits as ordinary income and to deduct any losses under the federal income $\operatorname{tax}^{133}$ Based on language in a private placeinent memorandum suggesting that investors should seek outside advice before investing, ${ }^{134}$ the court dismissed the case under Rule $9(\mathrm{~b})$ of the Federal Rules of Civil Procedure, stating that the plaintiffs failed to allege any facts supporting a rational inference that the representations in the placement meinorandum were false when made. ${ }^{135}$ The plaintiffs alleged that the defendants had looted the partnership through sham monetary transfers between the partnerships and affiliated corporations in the form of commissions and fees. ${ }^{136}$ Churning and breach of contract would appear to raise an inference that the defendants never intended to uphold their duties under the limited partnership, and therefore representations regarding potential returns may have been false when made. As indicated by Hayden and Amcoal, plaimtiff sophistication is sometimes used by courts to justify an expansive interpretation of the bespeaks caution doctrine. This expansive interpretation, however, borders on the common law doctrine of caveat emptor and gives culpable defendants an excuse because of the plaintiff's perceived cupidity. ${ }^{137}$

131. Id. at $* 5$.

132. 753 F. Supp. 116 (S.D.N.Y. 1990).

133. Id. at 117 .

134. Id. at 120.

135. Id. at 120-21.

136. Id. at 118.

137. While private rights of action are not the sole deterrence mechanism that the securities laws provide, they may be the most effective in some cases. See Berner v. Lazzaro, 730 F.2d 1319, 1322-23 (9th Cir. 1984) ("The resources of the Securities Exchange Commission are adequate to prosecute only the most flagrant abuses. To this end, private actions brought by investors have long been viewed as a necessary supplement to SEC enforcement actions.") (citations omitted), affd sub nom. Bateman Eichler, Hill 
To be sure, in soine cases the tension between deterring fraudulent statements by issuers and the exigencies of capital forination in an efficient market results in the denial of recovery to plaintiffs. As some courts have indicated, the federal securities laws were not designed to defend sophisticated investors from bad investnient decisions. ${ }^{138}$ Common law defenses such as estoppel, waiver, and in pari delicto operate to deny plaintiff recovery. ${ }^{139}$ However, these defenses are limited and usually apply only when the plaintiff is equally culpable for any wrongdoing as the defendant. ${ }^{140}$ Further, while cautionary language does not insulate an issuer from liability for fraud related to forward-looking statements when the issuer knew the stateinents were fraudulent at the time, or when the issuer did not have a reasonable basis to believe in the truth of the statements, ${ }^{141}$ it is not certain that these principles necessarily operate to limit the scope of the doctrine. Because the bespeaks caution doctrine ends actions before discov-

Richards, Inc. v. Berner, 472 U.S. 299 (1985); INSIDER TRADING SANCTIONS ACT OF 1983, H.R. REP. No. 355, 98th Cong., 1st Sess. 6 (1983) ("In recent years, the securities markets have grown dramatically in size and complexity, while Commission enforcement resources have declined."). SEC enforcement actions are not foreclosed by reasonable reliance and due diligence defenses. However, the possibility of private litigation along with the possibility of SEC enforcement action is necessarily a more effective in terrorem sanction than the possibility of SEC action alone. See supra note 122. This is also the implicit holding in Mills v. Electric Auto-Lite Co., 396 U.S. 375 (1970). The Supreme Court reversed the Seventh Circuit's holding that no remedy would be available absent a showing of harm and allowed plaintiffs to recover their attorneys fees. Mills, 396 U.S. at 384-85. By so holding, the Court recognized the value of private rights of action in enforcing the federal securities laws.

138. See, e.g., Hirsch v. du Pont, 553 F.2d 750, 763 (2d Cir. 1977); Hecht v. Harris, Upham \& Co., 283 F. Supp. 417, 428 (N.D. Cal. 1968) (stating that the Exchange Act was not intended to protect investors who lose their innocence, and then wait and see how investments turn out before invoking Exchange Act protections), modified on other grounds, 430 F.2d 1202 (9th Cir. 1970).

139. See Bateman Eichler, Hill Richards, Inc. v. Berner, 472 U.S. 299, 310-11 (1985); see generally John P.A. Bell, How to Bar an Innocent Investor-The Validity of Common Law Defenses to Private Actions Under the Securities Exchange Act of 1934, 23 U. FLA. L. REV. 1 (1970) (discussing how a securities plaintiff can be denied recovery based on tort concepts of wrongful conduct or maxims of equity such as in pari delicto).

140. In Bateman Eichler, the Supreme Court stated that in circumstances in which the plaintiff is as culpable for her injury as the defendant, the "preclusion of suit would not significantly interfere with the effective enforcement of the securities laws and protection of the investing public." Bateman Eichler, 472 U.S. at 311.

141. See Virginia Bankshares, Inc. v. Sandberg, 501 U.S. 1083, 1090-98 (1991) (holding that directors who make statements of belief that they do not actually believe may be liable for misstatements of material fact related to the statements in question, but that such disbelief alone is not a sufficient basis to sustain an action). 
ery and trial, it is difficult for plaintiffs to obtain sufficient evidence to show the issuers' subjective behef concerning the issuers' opinions. ${ }^{142}$ When added to the Rule 9(b) requirement that plaintiffs plead fraud with particularity, significant hurdles to trial exist even when a defendant may be acting with sufficient scienter to support a claim for fraud. ${ }^{143}$

\section{B. Courts Should Not Consider Market Information When Deter- mining the Sufficiency of Cautionary Language}

Congressional intent and the language of the securities laws are ambiguous with respect to whether information outside of that provided by issuers should be considered in applying the doctrine. ${ }^{144}$ Sections 11 and 12(2) of the Securities Act as well as section 10(b) and Rule 10b-5 of the Exchange Act do not address the scope of information to be considered in determining materiality or reasonable reliance. ${ }^{145}$ Because the language of the securities laws and congressional intent do not explicitly resolve this question, the policy enbodied in the securities laws must be considered. An analysis of these policy considerations reveals that limiting cautionary language to written or spoken statements by issuers accords with the purpose of the federal securities laws to protect investors while providing enougl protection to issuers to encourage forward-looking statements.

A definition of "context" limited to statements by issuers still provides protection to forward-looking statements by issuers. Courts that cite the bespeaks caution doctrine implicitly support a four-corners approach to analyzing cautionary language. ${ }^{146} \mathrm{Cau}-$ tionary language cannot be matched up against allegedly mislead-

142. Provenz v. Miller, No. C-92-20159, 1994 WL 485925, at *6 (N.D. Cal. June 27, 1994) (stating that cautionary language undercuts inference of defendant's scienter with regard to section 10(b)); Ruff v. Genesis Holding Corp., 728 F. Supp. 225, 228 (S.D.N.Y. 1990) (stating that it may be difficult to prove scienter when warnings in offering literature "bespeak caution").

143. See William M. Richman et al., The Pleading of Fraud: Rhymes Without Reason, 60 S. CAL. L. REV. 959, 985-86 (1987) (describing the purpose of Rule 9(b) and noting that this Rule may be applied in a manner that essentially forecloses any cause of action).

144. See supra notes $115,121$.

145. See supra notes 70-94, 103-108 and accompanying text.

146. See, e.g., In re Donald J. Trump Casino Sec. Litig., 7 F.3d 357, 369 (3d Cir. 1993), cert. denied, 114 S. Ct. 1219 (1994); I. Meyer Pincus \& Assocs. v. Oppenheimer \& Co., 936 F.2d 759, 763 (2d Cir. 1991). 
ing statements one-to-one, but must be considered within the document as a whole. ${ }^{147}$ While excluding market information limits the scope of cautionary language, the four corners definition of context is inherently broad and protective of issuers because it does not permit plaintiffs to mischaracterize issuer statements that might appear misleading if read alone. Further, the bespeaks caution doctrine is applied so that written cautionary language controls alleged oral misstatements or omissions. As stated in Brown v. E.F. Hutton Group, ${ }^{148}$ "[A]ny reasonable investor knows to be somewhat wary of a selling agent's oral representations and to check them against the written inaterials." ${ }^{\text {149 }}$ Oral statements are not protected by the SEC safe liarbor rules unless they are reaffirmed in a subsequent SEC filing. ${ }^{150}$ Therefore, limiting cautionary language to language directly from the issuer still provides greater protection for issuers than the SEC safe harbor. A narrow definition of context only would preclude forward-looking statements from being qualified by information known to the market that is not directly attributable to the issuer.

The bespeaks caution doctrine also operates concurrently with other doctrines that are protective of issuers, vitiating the need for courts to apply an expansive view of the total mix of information in order to protect forward-looking statements by issuers from liability. Some other doctrines that protect issuers from liability in the context of forward-looking statements are (1) puffery, ${ }^{151}$ (2) no duty to disclose, ${ }^{152}$ (3) fraud-by-hindsight, ${ }^{153}$ and (4) truth-

147. In re Trump, 7 F.3d at 370-71.

148. 735 F. Supp. 1196 (S.D.N.Y. 1990), affd, 991 F.2d 1020 (2d Cir. 1993).

149. Id. at 1202; see also Davidson v. Wilson, 973 F.2d 1391, 1401 (8th Cir. 1992) (holding that investors were not justified in relying on oral representations that contradict the written materials); Ambrosino v. Rodman \& Renshaw, Inc., 972 F.2d 776, 786 (7th Cir. 1992) (stating that because written materials control oral statements, oral variances are not a basis for liabihity); Feinman v. Schulman Berlin \& Davis, 677 F. Supp. 168, 170-71 (S.D.N.Y. 1988) (holding that truthful written disclosure controls alleged false oral disclosure).

150. Safe Harbor Release, supra note 36 , at *4-5.

151. Raab v. General Physics Corp., 4 F.3d 286, $289-90$ (4th Cir. 1993). But see In re B. Fennekohl \& Co., [1961-64 Transfer Binder] Fed. Sec. L. Rep. (CCH) II 76,872, at 81,229-30 (Sept. 18, 1962) (rejecting application of the common law doctrine of caveat emptor, which tolerated puffing, to the merchandising of securities).

152. See Wielgos v. Commonwealth Edison Co., 892 F.2d 509, 516-18 (7th Cir. 1989).

153. Arazie v. Mullane, 2 F.3d 1456, 1467-68 (7th Cir. 1993) ("[T]emporal proxinity between positive statements stressing a firm's strengths and announcements of poor economic performance do not create an inference that the earlier statements were fraudulent."). 
on-the-market. ${ }^{154}$ Although these doctrines are similar in some respects, each is distinct from one another and from the bespeaks caution doctrine. Puffery is a claim that the forward-looking statements in question are harmless such that no reasonable investor could rely on them. Puffing statements need not be qualified by cautionary language. Similarly, if defendants have no duty to disclose information, they cannot be liable for its omission, regardless of the materiality of that information or their intent. The fraud-byhindsight doctrine restates the principle tliat forward-looking statements made in good faith and with a reasonable basis are not actionable. The truth-on-the-market defense requires that in an efficient capital market, a body of public information exists that allows defendants to rebut the presumption of reliance based on the fraud-on-the-market theory. ${ }^{155}$

The efficient capital market hypothesis should not be applied in bespeaks caution cases. Issuers are uniquely capable of providing cautionary language to investors in a prospectus or other offering documents. It is not the market or the security itself that should be understood to be "bespeaking caution" but the cautionary statements by the issuer. The cost to issuers is minimal in this regard. Therefore, issuers should disclose assumptions that underlie their cautionary language, even if these assumptions involve general statements that are likely to be already in the public domain. While the efficient market hypothesis argues that the market as a whole impounds information about an issuer, ${ }^{156}$ higlily efficient markets exist for only the largest issuers. ${ }^{157}$ Inefficient markets are especially prevalent in the case of initial public offerings and private placements, ${ }^{158}$ contexts in which the majority of bespeaks

154. See In re Apple Computer Sec. Litig., 886 F.2d 1109, 1116 (9th Cir. 1989) (fraudon-the-market reliance rebutted when sufficient truthful information in market), cert. denied, 496 U.S. 943 (1990).

155. See Hanon v. Dataproducts Corp., 976 F.2d 497, 503 (9th Cir. 1992) (no defense to fraud-on-the-market claim when there is no press information regarding risks of investment).

156. See supra note 86 and accompanying text.

157. See REPORT OF THE ADVISORY COMMITTEE ON CORPORATE Disclosure, 95th Cong., 1st Sess., Report of the Sec. Exch. Comm'n, at xviii-xix, 40-42 (Comm. Print 1977) (fewer than 1,000 of the more than 10,000 companies filing SEC reports were followed closely by one or more analysts at any time); see also Williain K.S. Wang, Some Arguments That the Stock Market is Not Efficient, 19 U.C. DAvIS L. REv. 341, 357 (1986).

158. See Louis Lowenstein, Shareholder Voting Rights: A Response to SEC Rule 19c-4 and to Professor Gilson, 89 CoLUM. L. REv. 979, 991-1000 (1989) (arguing that 
caution cases occur. ${ }^{159}$ Therefore, limiting cautionary language to statements by issuers will not affect most cases while providing predictability for all. Further, the efficient-market hypothesis recognizes that information from different sources has different impacts on the market. ${ }^{160}$ Therefore, the statements of analysts or journalists cannot necessarily rebut forward-looking statements by issuers. The vahidity of the efficient capital market hypothesis is itself in question. ${ }^{161}$

Market information should not be considered under the bespeaks caution doctrine by combining the doctrine with other issuer-protective doctrines. Courts that currently consider market information under the rubric of bespeaks caution sometimes hybridize issuer-protective doctrines. As noted above, although issuerprotective doctrines do overlap in some respects, they are distinct. For example, in In re Northern Telecom Ltd. Securities Litigation, ${ }^{162}$ the court appears to mix puffery with the bespeaks caution doctrine. The court in Northern Telecom stated that allegations in a complaint must be "considered as a whole and the statements challenged in the coinplaint must be viewed in context." ${ }^{163}$ The court then held that the plaintiffs could not reasonably rely on the representations in question, citing the bespeaks caution doctrine ${ }^{164}$ and the puffery doctrine ${ }^{165}$ in alternate paragraphs as part of the context without discussing their relation. Either the statements should be nonmaterial $a b$ initio under the puffery doctrine or they should be considered material but rendered immaterial as a matter of law under the bespeaks caution doctrime. The latter proposition opens the door to pleading that

investors' lack of information results in added weight being given to issuers' evaluations of assets, liabilities, and risks associated with a nascent business and their relevance to the future of the business in context of an initial public offering).

159. Langevoort, supra note 16, at 483.

160. See supra note 89 and accompanying text.

161. See, e.g., Lawrence A. Cunningham, Capital Market Theory, Mandatory Disclosure, and Price Discovery, 51 WASH. \& LEE L. REV. 843 (1994) (arguing that the efficient capital market hypothesis is flawed and that markets are better described by means of chaos theory); Wang, supra note 157, at 363-66.

162. [1994-1995 Transfer Binder] Fed. Sec. L. Rep. (CCH) If 98,390, at 90,657 (S.D.N.Y. Aug. 19, 1994).

163. Id. at 90,661 .

164. Id. at 90,662 .

165. The court held that soine of the defendant's "statements . . . are the sort of vacuous truisms and bland 'corporate-speak' that no rational investor would consider material." Id. at 90,661. 
the defendants lacked good faith or a reasonable basis for making the forward-looking statements in question.

The tendency toward hybridization is especially pronounced with respect to bespeaks caution and truth-on-the-inarket claims. In Porter v. Shearson Lehman Brothers Inc. ${ }^{166}$ the district court held that written cautionary statements in the prospectus control alleged oral misstateinents. ${ }^{167}$ The court then went on to say that the plaintiffs could not reasonably rely on the alleged misstatements when considered in light of the cautionary language im the prospectus and of the information in the public domain. ${ }^{168}$ However, either the cautionary stateinents in the written document slould immunize the alleged misstatements under bespeaks caution or the information in the public doinain should immunize the alleged misstateinents under truth-on-the-market. While the cautionary statements are themselves in the public doinain, the truthon-the-1narket defense requires a slowing that (1) the market is efficient, and (2) that the information in the public doinain is intense enough to neutralize the misstatements. ${ }^{169}$ As stated by the district court in In re Taxable Municipal Bonds Litigation, ${ }^{170}$ "Courts allowing the [truth-on-the-inarket] defense have emphasized the strict evidentiary standards a defendant inust ineet to rebut the rehance presumption in this manner. The determination is fact intensive and, therefore, the defendants liave an onerous burden on summary judgment." 171

Similarly, In re Worlds of Wonder Securities Litigation ${ }^{172}$ is illustrative of the expansive interpretation courts give the bespeaks caution doctrime when they consider cautionary language in the market at large. ${ }^{173}$ Worlds of Wonder, a company that experi-

166. 802 F. Supp. 41 (S.D. Tex. 1992).

167. Id. at 57 .

168. Id. at 58.

169. See supra note 155 and accompanying text.

170. [1994-1995 Transfer Binder] Fed. Sec. L. Rep. (CCH) II 98,405 (E.D. La. Sept. 26, 1994).

171. Id. at 98,405 . The evidentiary burden for a truth-on-the-market claim even may require an event study based on regression analysis to show that the market impounded enough truthful imformation to neutralize the allegedly misleading statements. Id. This essentially sets the stage for a battle of experts, which should be resolved by the finder of fact.

172. 35 F.3d 1407 (9th Cir. 1994), aff'g in part, rev'g in part 814 F. Supp. 850 (N.D. Cal. 1993), cert. denied, 116 S. Ct. 277 (1995).

173. See generally Harold S. Bloomenthal, The Securities Act vs. Bespeaks Caution: In 
enced tremendous growth based on sales of Teddy Ruxpin, the talking bear, conducted a public offering of "junk bonds" in 1987. ${ }^{74}$ In the bond prospectus, Worlds of Wonder projected that it could meet its capital needs until the end of March 1988. ${ }^{175}$ In a section of the prospectus entitled "Risk Factors," Worlds of Wonder histed some grounds for the unreliability of its projection as to liquidity. ${ }^{176}$ Within one montl following the bond Offering, Worlds of Wonder defaulted on the first bond payment. ${ }^{177}$ Investors sued under sections 11 and 12(2) of the Securities Act and section 10(b) of the Exchange Act. ${ }^{178}$ The Ninth Circuit affirmed the district court's entry of summary judgment on the relevant claims.

The Ninth Circuit stated that the cautionary language at bar sufficed when analyzed in the context of (1) the bond prospectus as a whole combined with (2) information known to the market at the time of the offering concerning the risk of junk bonds and the uncertainties of the toy industry. ${ }^{179}$ However, problems with capitalization and overextension, which were a significant part of

Defense of the Securities Act-Part II, 16 SEC. \& FED. L. REP. 169 (1994).

174. A junk bond is a bond that bears an above-market interest rate to compensate for the risk associated with its below investment grade rating. See Worlds of Wonder, 35 F.3d at 1411. The bonds in the Worlds of Wonder offering were subordinated debentures paying $9 \%$, convertible at $\$ 17.50,20 \%$ above the then-market price of Worlds of Wonder common stock. James P. Miller, Worlds of Wonder Trims Debt Offer to $\$ 80$ Million, WALL ST. J., June 5, 1987, at 47.

175. Worlds of Wonder, 35 F.3d at 1415.

176. See In re Worlds of Wonder Sec. Litig., 814 F. Supp. 850,863 (1993), aff'd in part, rev'd in part, 35 F.3d 1407 (1994), cert. denied, 116 S. Ct. 277 (1995). Worlds of Wonder cautioned that its projection of hquidity was contingent because it was based on Worlds of Wonder's dependence on a single product line, the competition in the highly competitive toy market, and heavy dependence on accounts receivable. Id. at 860,863 . For example, under "Management's Discussion and Analysis of Financial Condition and Results of Operations-Liquidity and Capital Resources," the company stated:

Since its inception, the Company's internally generated cash flow has not been sufficient to finance accounts receivable, imventory and capital equipinent needs, as well as support its growth. The Company has met its capital requirements to date primarily through borrowings under bank limes of credit, the private and public sale of equity securities and borrowings under subordinated notes payable to shareholders.

Id. at 863 .

177. The default apparently resulted from a general downturn in the toy market, production and delivery problems, and too much debt. Id. at 854-55.

178. Id. at 853 . Investors also brought suit on the sale of stock im an initial public offering in 1986. Id. at 855 .

179. See Worlds of Wonder, 35 F.3d at 1413, 1415. 
Worlds of Wonder's failure, ${ }^{180}$ are precisely the type of company-specific information that should be disclosed. ${ }^{181}$ The counterpoint to Worlds of Wonder may be seen in Forrester v. Microtest, Inc., ${ }^{182}$ a case in which an Arizona district court dismissed section 11 claims, noting that "[t]he registration statement . . . specifically stated that the industry was risky, profits were volatile, and the failure of one product could really impact the success of the company."183 Indeed, in Worlds of Wonder the riskiness of the market apparently did not discount the value of securities offered, which sold at a premium despite Worlds of Wonder's precarious cash position. ${ }^{184}$

\section{CONCLUSION}

The federal securities laws reject the common law notion that the cautionary words caveat emptor should guide the capital markets. At the same time, the necessity of remaining competitive in global capital markets precludes the overly paternalistic regulation of securities. In the case of forward-looking statements, however, market efficiency may be inadequate to protect investors because such statements are weighted disproportionately by analysts and investors relative to other information in the market. Indeed, as Congress and the SEC strengthen safe harbors for forward-looking information, requiring issuers to invoke these safe harbors based only on their own statements is a sensible counterbalance to what some perceive as a move toward overly laissez-faire regulation of such soft information. The real cost to some issuers is that less analysts and investors will be likely to be misled by overly optimistic projections, predictions, and forecasts. For most issuers, the

180. See id. at 1411-12.

181. This is especially significant given Worlds of Wonder's propensity to be overly optimistic about its prospects for the future in public statements. See Carrie Dolan, Changing Fortunes: Yesterday's Marvel, Worlds of Wonder Inc. Is in Worlds of Trouble, WALL ST. J., Oct. 28, 1987, at A4 (“'Management [of Worlds of Wonder] hasn't been as credible as the Street would have liked,' says Steven Eisenberg, a Bear, Stearns \& Co. analyst. 'They're clearly too optimistic.' Adds analyst Mark Friedman of Boston's Homans, McGraw, Trull, Valeo \& Co.: 'There's a lot of overhype by the company.' ").

182. [1993-1994 Transfer Binder] Fed. Sec. L. Rep. (CCH) II 98,072, at 98,639 (D. Ariz. Nov. 15, 1993).

183. Id. at $98,641-42$.

184. See In re Worlds of Wonder Sec. Litig., 814 F. Supp. 850, 854 (N.D. Cal. 1993), aff'd in part, rev'd in part, 35 F.3d 1407 (9th Cir. 1994), cert. denied, 116 S. Ct. 277 (1995). 
limits to the doctrine suggested by this Note will provide brighter lines and greater predictability when making forward-looking stateinents. 